\title{
Northward cooling and freshening of the warm core of the West Spitsbergen Current
}

\author{
Tuomo M. Saloranta \& Peter M. Haugan
}

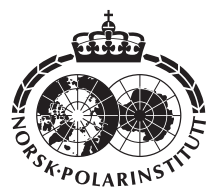

The narrow slope-confined warm core of the West Spitsbergen Current (WSC) is a major pathway for warm and saline Atlantic Water to enter the Arctic Ocean. Long-term mean northward cooling and freshening rates in the warm core of the WSC are calculated with error ranges, and heat loss estimates are derived. The observed combination of cooling and freshening is not consistent with a hypothesis of pure isopycnal offshore mixing, but rather suggests influence from diapycnal mixing connected, for example, to exchange with shelf waters.

T. M. Saloranta, Norwegian Institute for Water Research, Box 173 Kjelsås, NO-0411 Oslo, Norway, tuomo. saloranta@niva.no; P. M. Haugan, Geophysical Institute, University of Bergen, Allégaten 70, NO-5007 Bergen, Norway.

The West Spitsbergen Current (WSC) (Fig. 1) has classically been considered as the major pathway both for heat and volume transport to the Arctic Ocean (Aagaard \& Greisman 1975). The Barents Sea branch (Fig. 1) has received increasing attention in recent years and is now considered to be as significant as the WSC branch for volume transport (Rudels et al. 1994; Loeng et al. 1997; Schauer et al. 1997; Rudels et al. 1999). The waters in the Barents Sea branch are, however, generally cooler than in the WSC owing to larger heat loss during their transit of the Barents Sea (Simonsen \& Haugan 1996; Rudels \& Friedrich 2000; Schauer et al. 2002).

The mean temperature, current speed and topographic steering in the WSC all have been observed to increase towards the shelf break (Hanzlick 1983; Jónsson et al. 1992; Poulain et al. 1996; Woodgate et al. 1998; Fahrbach et al. 2001; Saloranta 2001) (Fig. 1). Owing to this, and since much of the warm Atlantic Water (AW) in the offshore branches of the WSC actually recirculates in or near Fram Strait to the Greenland Sea (Bourke et al. 1988; Gascard et al. 1995), it is especially the part of the WSC confined over the upper part of the continental slope of Svalbard (i.e. the warm core of the WSC) which feeds the major input of sensible heat into the Arctic Ocean (Gammelsrød
\& Rudels 1983; Aagaard et al. 1987; Bourke et al. 1988; Gascard et al. 1995; Manley 1995) (Fig. 1). Therefore, as Haugan (1999a) and Saloranta \& Haugan (2001a) emphasized, it may be important to focus on this narrow subset of the WSC to get consistent estimates of the Arctic Ocean inflow signal in Fram Strait.

Based on both observations and numerical models, studies by Quadfasel et al. (1993), Washington \& Meehl (1996), Swift et al. (1997), Grotefendt et al. (1998), Zhang et al. (1998) and Zhang \& Hunke (2001), for example, have indicated a recent warming in the subsurface Arctic Ocean, in the so-called Atlantic layer. This warming was in these studies attributed to increased heat transport both in the WSC and in the Barents Sea branch. The relative importance of these two pathways in the recent Atlantic layer warming is still uncertain.

For reliable estimates of the historical WSC heat transport both temperature and current records are needed. While there are continuous interannual time series of the WSC summer/ autumn hydrography since the late 1960s (Blindheim et al. 2000; Saloranta \& Haugan 2001a), longer interannual time series of the WSC speed and transport are not available. Furthermore, few data are available from the winter season. 


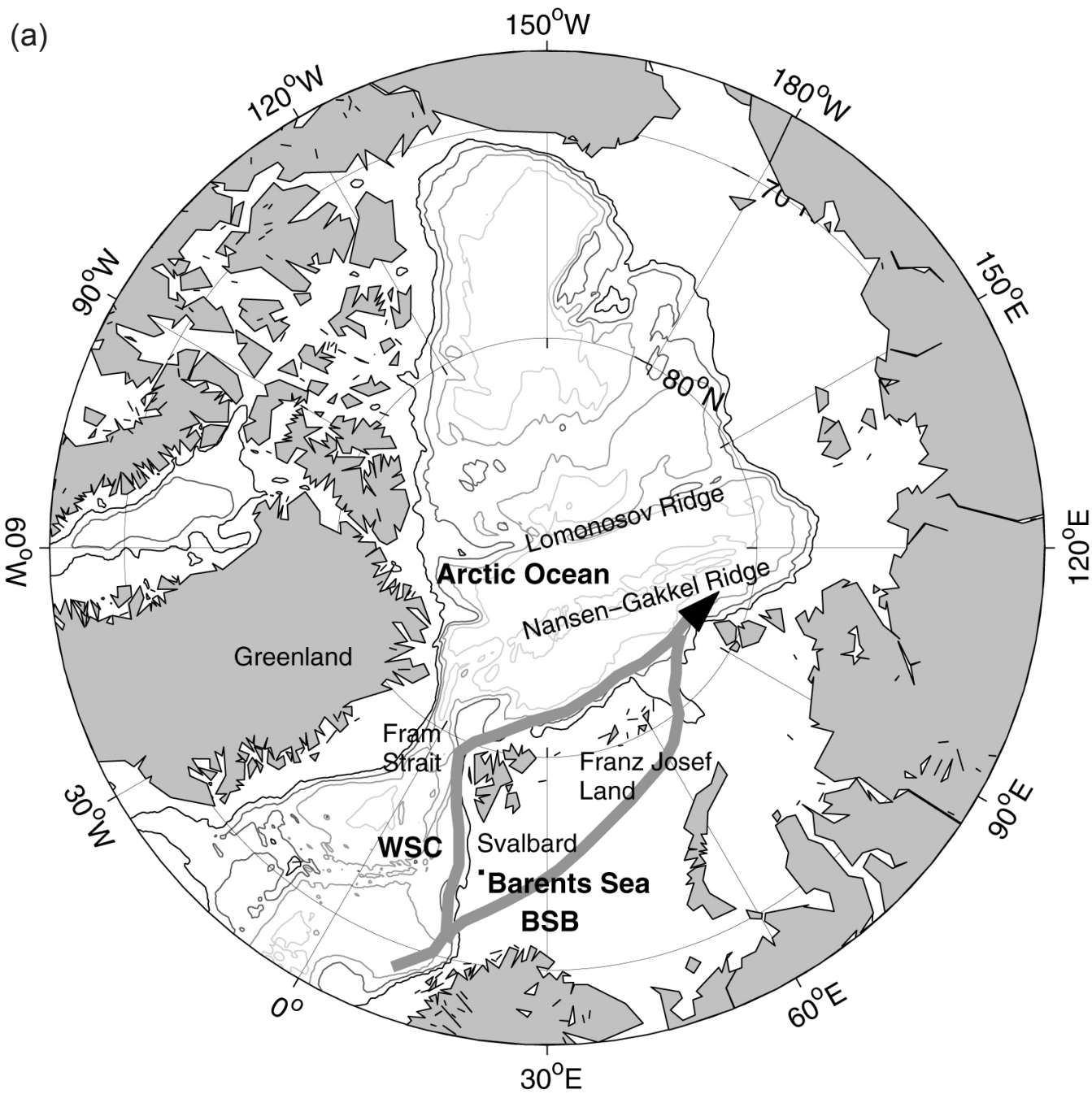

Fig 1: (a) Two pathways to the Arctic Ocean, the West Spitsbergen Current (WSC) and the Barents Sea branch (BSB). (b, opposite page) Schematic illustration of the current patterns in the sea west of Svalbard, based on Johannessen (1986), Loeng (1991) and Gascard et al. (1995). Grey arrows denote warm currents of Atlantic origin and black arrows colder currents of Arctic origin. Dashed line denotes the Arctic Front west of Spitsbergen. (From Saloranta \& Svendsen 2001.) (c, opposite page) Schematic cross-section across the continental slope showing the warm and saline WSC on the slope and the cooler and fresher waters on the shelf. Dashed lines denote our upper-slope domain with which we approximate the warm core of the WSC. The arrow denotes the direction to which temperature, current speed and topographic current steering in the WSC increase. The illustration is based on Hanzlick (1983); Jónsson et al. (1992); Poulain et al. (1996); Woodgate et al. (1998); Fahrbach et al. (2001); Saloranta (2001) and Saloranta \& Svendsen (2001).

To predict future changes in the WSC heat transport, understanding of the physics of both the WSC volume transport and its heat content is essential. This paper focuses on the latter, namely, on quantifying the long-term northward cooling and freshening. We know that on its way toward the Arctic the WSC loses heat, and that one part of this cooling is due to heat loss directly into the atmosphere. Some heat could also be lost to melting of sea ice, while another part of the heat in the WSC is lost due to mixing with colder surrounding waters (by the term "mixing" we assume that the total water volume is conserved) and due to westward recirculation into the Greenland Sea. However, it is not well known what processes, circumstances and external factors are responsible 


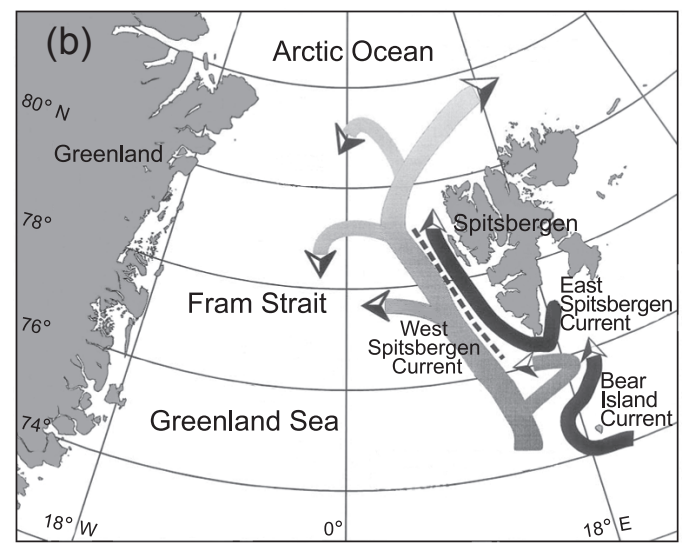

or control this cooling, especially in the deeper layers where direct vertical heat loss to atmosphere (over the current) cannot alone be responsible for all cooling (Boyd \& D'Asaro 1994).

Helland-Hansen \& Nansen (1912), Aagaard et al. (1987), Untersteiner (1988), Boyd \& D'Asaro (1994) and Gascard et al. (1995) have previously estimated cooling and heat loss in the WSC. Based on data from single cruises, these estimates are, however, spatio-temporally restricted and may therefore be biased by mesoscale variability and represent local and/or episodic events rather than large-scale climatic mean conditions. Manley (1995) estimated heat loss in the WSC using data from an 11-year period, but he focused only on changes within the Atlantic Water class.

In this paper we present long-term mean northward cooling and freshening rates in the warm core of the WSC between $74^{\circ}$ and $79^{\circ} \mathrm{N}$ with error and heat loss estimates. We compare our cooling and freshening rates to previously published "snapshot estimates" and discuss some relevant cooling mechanisms. Our results could serve as a basis for testing the appropriateness of ocean circulation models (e.g those embedded in climate models) in the area.

\section{Data and methods}

Quality controlled hydrographic data for this study were kindly provided by the International Council for the Exploration of the Sea, the International Arctic Climate System Study project office (BarKode CD-rom), the Norwegian Institute of Marine Research and the Norwegian Polar Institute. In addition, CTD data from cruises of

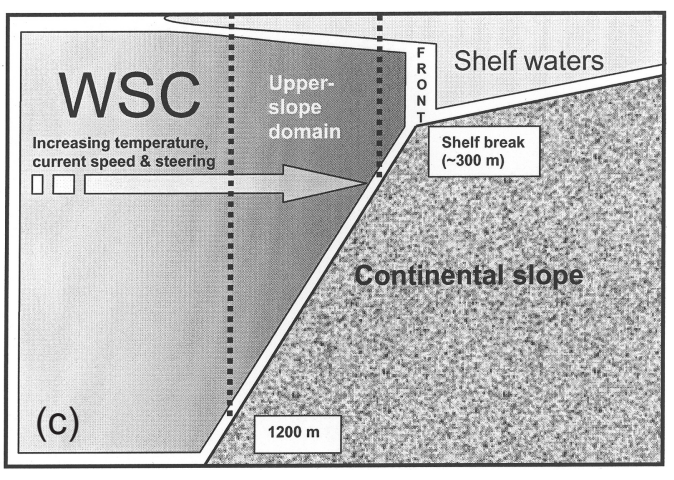

the University of Bergen's research vessel, the Håkon Mosby, in September 1998 and 1999 are used. The hydrographic data were screened for duplicates and then each vertical sounding was linearly interpolated to a uniform grid with $10 \mathrm{~m}$ resolution in the $0-50 \mathrm{~m}$ layer and $25 \mathrm{~m}$ in the $50-500 \mathrm{~m}$ layer (for more details of the data gridding and post-processing, see Saloranta 2001).

We focus on the period 1949-1999 and define the summer season as August-October and the winter season as March-May. As our main focus is the warm core of the WSC confined over the upper part of the continental slope, we correspondingly define our study area, the "upper-slope domain", as the area between $74^{\circ}$ and $79^{\circ} \mathrm{N}$, and between the $500 \mathrm{~m}$ and $1200 \mathrm{~m}$ isobaths which are situated approximately by the shelf break and in the middle of the continental slope, respectively (Fig. 2). Bottom topography (Fig. 2) in our study is based on the International bathymetric chart of the Arctic Ocean (Jakobsson et al. 2000). The distribution of stations in the upper-slope domain in the summer and winter is shown in Fig. 3. We note that our winter results are generally based on data with poorer spatio-temporal coverage than in the summer and are therefore more affected by random fluctuations and transient phenomena.

For the purpose of bin-averaging of the hydrographic data, the upper-slope domain was divided in south-north direction into five bins of $1^{\circ}$ of latitude $\left(74^{\circ}-75^{\circ}, 75^{\circ}-76^{\circ}\right.$ etc.). Although the slope is meandering somewhat, its length (measured along the $1200 \mathrm{~m}$ isobath) per bin is relatively constant: $122-136 \mathrm{~km}$. We use a slope length of $130 \mathrm{~km}$ per degree in conversions between degrees of latitude and kilometres. The total length of the slope from $74^{\circ}$ to $79^{\circ} \mathrm{N}$ is ca. $640 \mathrm{~km}$.

The northward along-slope gradients in temperature $(d T / d y)$ and salinity $(d S / d y)$ are defined 


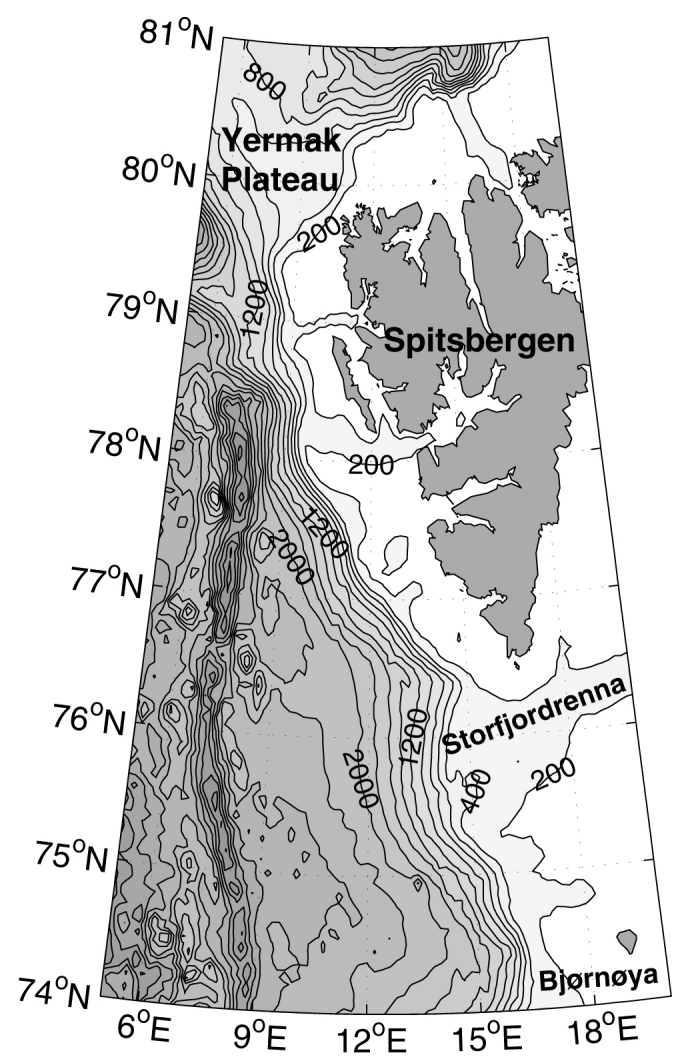

Fig. 2. Bathymetry of the sea west of Svalbard (based on the International bathymetric chart of the Arctic Ocean; Jakobsson et al. 2000). Contours are drawn at $200 \mathrm{~m}$ depth intervals.

as the coefficient $b_{1}$ of the linear regression line $p=b_{0}+b_{1} y$ (where $p$ denotes temperature or salinity and $y$ denotes the north-south coordinate [degree of latitude or distance on the slope]) fitted to the particular year's mean summer/winter temperature and salinity values in the five bins using the method of least squares. Negative gradient values therefore denote cooling and freshening northwards, and positive values warming and salinification.

Mean values from all five bins are required in the regression in the summer, and mean values from the southernmost and northernmost bins in the winter. If these conditions are not met, no regression is calculated for the particular year/ season. Finally, by averaging over all the yearly mean summer/winter gradients we get the longterm mean summer/winter gradients for temperature $\left(d T^{*} / d y\right)$ and salinity $\left(d S^{*} / d y\right)$ presented in
Fig. 4 (we denote long-term means with an asterisk). Their standard error (SE) is calculated from $s / \sqrt{N}$, where $s$ is the sample standard deviation and $N$ is the number of averaged years. $N$ varies somewhat with depth level, being 17-21 in the summer and 5-6 in the winter.

\section{Results}

The results in Fig. 4 show that, in the summer, $d T^{*} / d y$ and $d S^{*} / d y$ patterns in the upper-slope domain are clearly divided into two regimes, above and below ca. $50 \mathrm{~m}$ depth. $d T^{*} / d y$ and $d S^{*} /$ $d y$ have maxima in cooling and freshening at the surface, but these values decrease strongly with depth in the 0-50 m layer. Below ca. $75 \mathrm{~m}, d S^{*} / d y$ is quite constant with depth, while $d T^{*} / d y$ shows slightly increasing cooling down to $200 \mathrm{~m}$ depth, and decreasing cooling again below that. In the winter (Fig. 4), northward cooling and freshening values decrease more smoothly with depth, and the distinct surface regime seen in the summer season is absent. In the winter, $\left|d T^{*} / d y\right|$ is in the $0-500 \mathrm{~m}$ layer on average ca. $50 \%$ larger than in the summer, while $\left|d S^{*} / d y\right|$ is slightly smaller (Table 1).

We also examined if there were any longterm trends in the time series of $d T / d y$ and $d S / d y$ values. Figure 5 shows such time series from 0 , 200 and $400 \mathrm{~m}$ depths, from summer and winter. No significant long-term trends (at $90 \%$ level of significance) could be detected (most of the $p$ values were $>0.5$ ). Of the three $d S / d y$ outliers, the two summer outliers in 1977-78 are likely to rep-

Table 1. Long-term mean northward along-slope gradients in temperature $\left(d T^{*} / d y\right)$ and salinity $\left(d S^{*} / d y\right)$ in the upper-slope domain. A nominal current speed $(v)$ of 0.1 and $0.2 \mathrm{~m} \mathrm{~s}^{-1}$, based on Fahrbach et al. (2001), are used in summer and winter, respectively, to calculate the depth-integrated mean heat loss rates $Q_{a}^{*}$ (Eq. 2) for the water column illustrated in Fig. 6.

\begin{tabular}{|c|c|c|c|c|}
\hline & $\begin{array}{l}\text { Layer, } z_{1}-z_{2} \\
\text { (m) }\end{array}$ & $\begin{array}{c}d T^{*} / d y \\
\left({ }^{\circ} \mathrm{C} / 100 \mathrm{~km}\right)\end{array}$ & $\begin{array}{c}d S^{*} / d y \\
(\mathrm{psu} / 100 \mathrm{~km})\end{array}$ & $Q^{*}(\mathrm{~W})$ \\
\hline \multirow{3}{*}{ 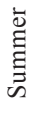 } & $0-100$ & -0.32 & -0.028 & -130 \\
\hline & $100-500$ & -0.20 & -0.010 & -330 \\
\hline & $0-500$ & -0.22 & -0.013 & -460 \\
\hline \multirow{4}{*}{ 离 } & $0-100$ & -0.42 & -0.025 & -350 \\
\hline & $0-250$ & -0.40 & -0.016 & -830 \\
\hline & $100-500$ & -0.31 & -0.004 & -1050 \\
\hline & $0-500$ & -0.34 & -0.008 & -1400 \\
\hline
\end{tabular}


Fig. 3. Yearly, seasonal, meridional and spatial station distribution (all measurements at $10 \mathrm{~m}$ depth) in the upper-slope domain in the (a-d) summer and $(\mathrm{e}-\mathrm{h})$ winter. The total number of stations in the upper-slope domain is 479 in the summer and 88 in the winter. In (b) and (f), month is indicated so that, for example, the four bars between 9 and 10 denote September, etc. The two contours in the maps denote the $500 \mathrm{~m}$ and $1200 \mathrm{~m}$ isobaths.
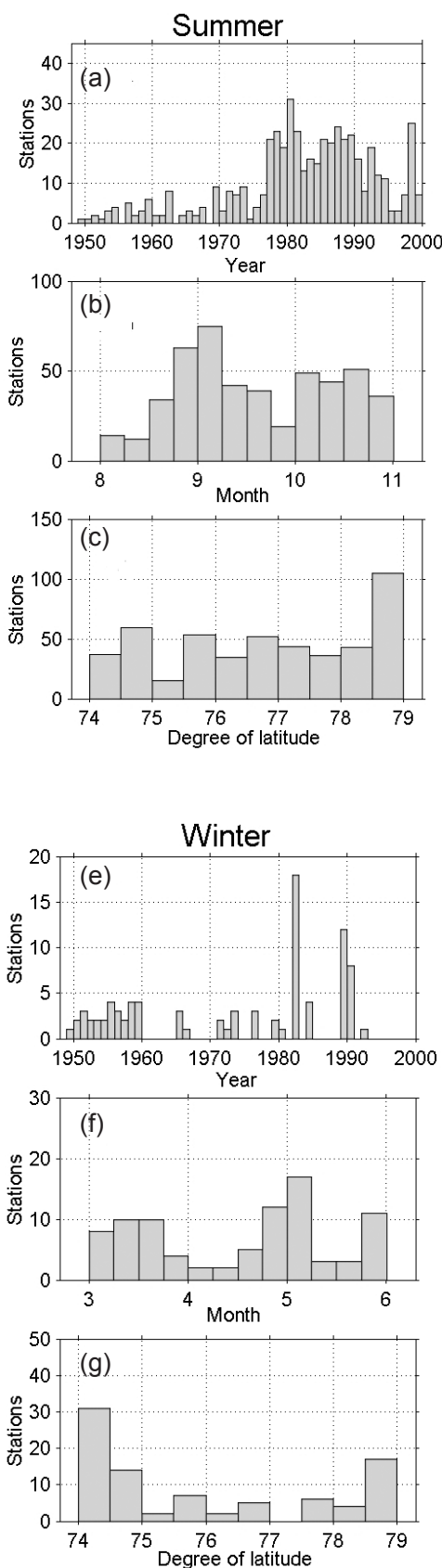
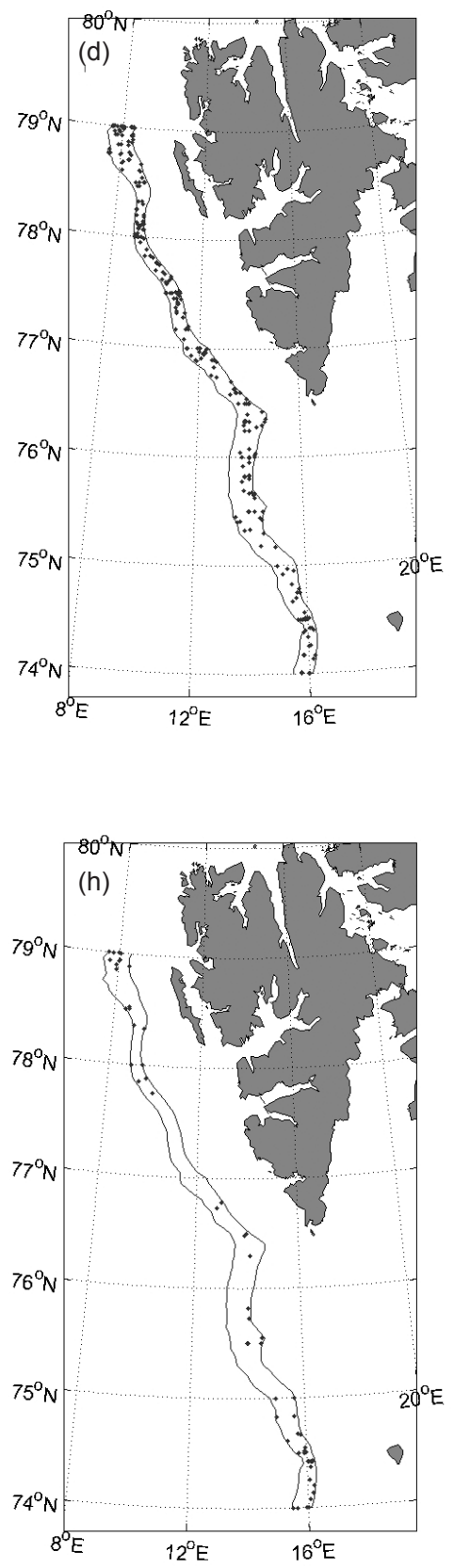

resent some real freshening events, since the gradient is based on values from all five bins, while the one outlier in winter 1990 is more likely due to spatio-temporal along-stream variation than due to a real salinification event.

Variability in the mean measurement date between the five bins could introduce bias to the estimates of $d T^{*} / d y$ and $d S^{*} / d y$ owing to the seasonal cycle of hydrography. This bias is, however, estimated to be small owing to the facts that: (1) the mean northward gradient in measurement day was small in the upper-slope domain: from -1 to -2 days per degree of latitude in the summer and from 0 to -2 days per degree of latitude in 


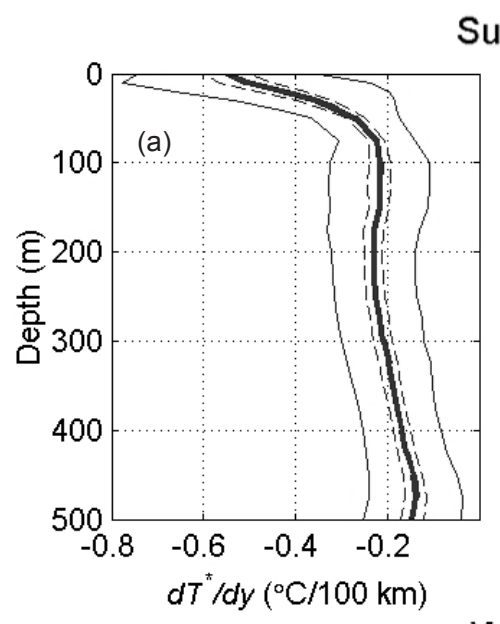

Summer

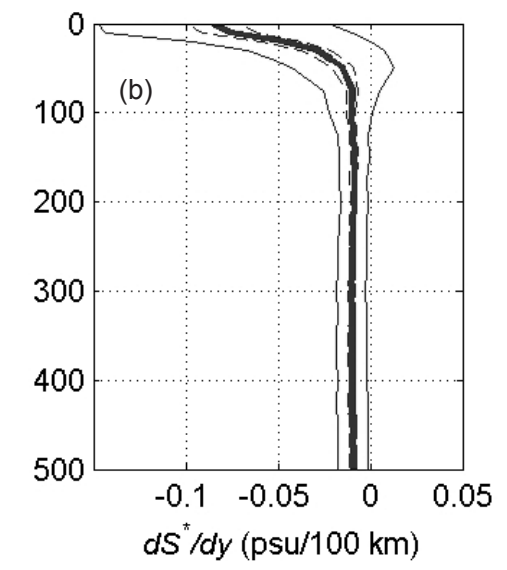

Fig. 4. Long-term mean northward along-slope gradients in (a) and (c) temperature $\left(d T^{*} / d y\right)$ and (b) and (d) salinity $\left(d S^{*} / d y\right)$ in the upper-slope domain in the summer and winter (thick lines). Thin dashed lines denote the standard error of the mean $( \pm \mathrm{SE})$. Thin solid lines denote the standard deviation of the averaged data. The total number of averaged years/seasons $(N)$ varies somewhat between depth level being $17-21$ in the summer and 5-6 in the winter.

\section{Winter}

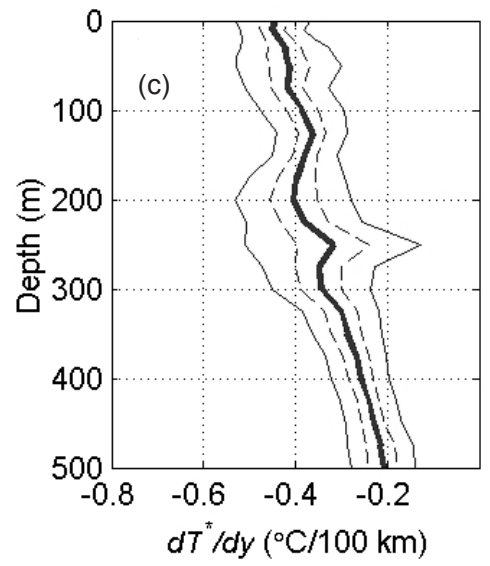

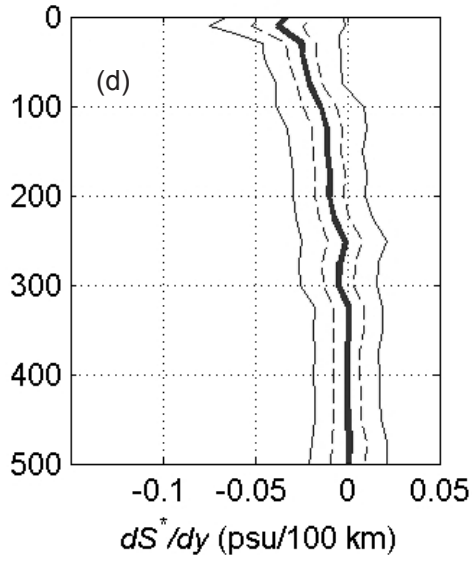

the winter; (2) our three-month time windows are roughly centred at the maxima and minima of the seasonal temperature cycle (broad maxima in autumn and minima in March-April [Hanzlick 1983; Morison 1991]) when $\partial T / \partial t$ is small; (3) the averaging, both within the time-windows and interannually, suppresses the influence of seasonal variability; and (4) the amplitude of the seasonal cycle decreases significantly with depth.

To estimate the heat loss from the upper-slope domain, consider the total time derivative for the temperature $d T / d t$ which can be divided into local and advective terms (in our case advection occurs only in one dimension along the slope), when following a particular parcel of fluid (e.g. Pond \& Pickard 1993):

$$
\frac{d T}{d t}=\frac{\partial T}{\partial t}+v \frac{\partial T}{\partial y}
$$

where $v$ is current speed.

Similarly, the total heat loss/gain $Q$, which is proportional to $d T / d t$, can be divided into local and advective parts $Q_{l}$ and $Q_{a}$.

Let us consider now a column of water in the WSC vertically limited between depths $z_{1}$ and $z_{2}$ and with fixed horizontal cross-section area $A$ of $1 \mathrm{~m}^{2}$ (Fig. 6). This column of water is assumed to move northwards along the continental slope with constant speed $v$. The heat loss rate $Q_{a}[\mathrm{~W}]$ connected to the column's northward advection and cooling along a steady temperature gradient $d T(z) / d y$ is

$$
Q_{a}=A c \rho v \int_{z_{1}}^{z_{2}} \frac{d T(z)}{\partial y} d z
$$

where $c$ is the specific heat of sea water and $\rho$ is sea water density.

Values for depth-averaged $d T^{*} / d y$ and $d S^{*} / d y$ 
Fig. 5. Northward along-slope gradients in (a-c) temperature $(d T / d y)$ and (d-f) salinity $(d S /$ $d y)$ in the upper-slope domain, at (a) and (d) $0 \mathrm{~m}$, (b) and (e) $200 \mathrm{~m}$, and (c) and (f) $400 \mathrm{~m}$ depths. Summer values are denoted with crosses and winter values with circles. Values of consecutive years are connected with lines.
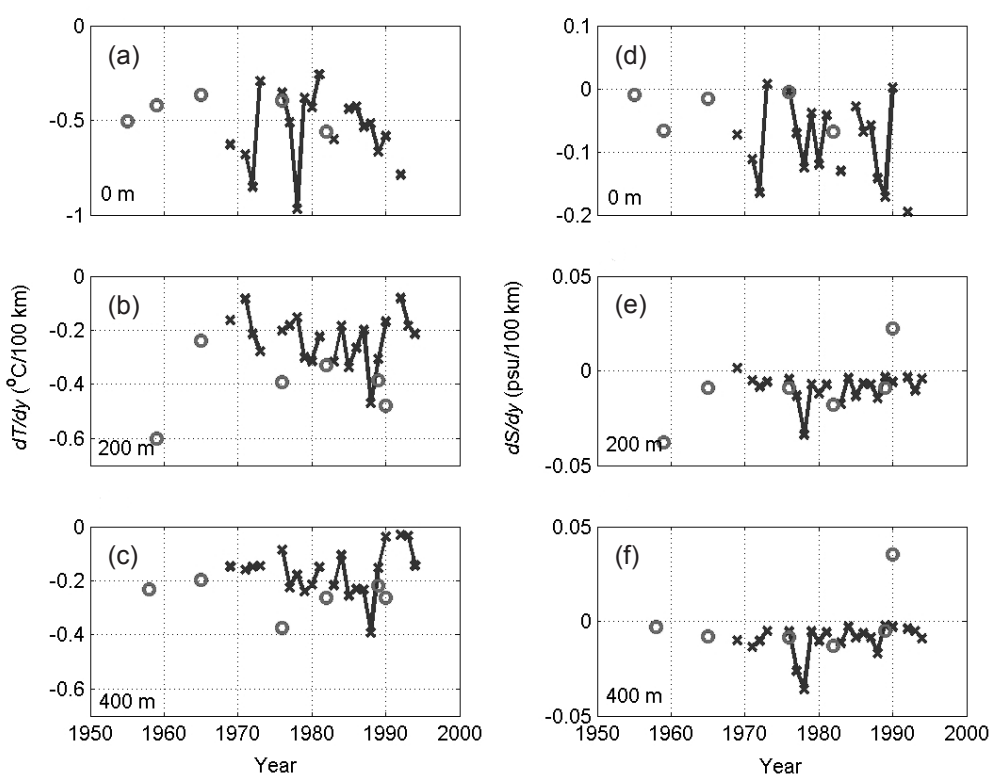

in the upper-slope domain are given in Table 1 with estimates of the mean heat loss rate $Q^{*}{ }_{a}$ of the corresponding water column $\left(z_{1}-z_{2}\right)$. In calculating $Q^{*}$, a nominal current speed $v$ of 0.1 and $0.2 \mathrm{~m} \mathrm{~s}^{-1}$ is used in summer and winter, respectively, based on Fahrbach et al. (2001). The same $v$ can be applied for all depth layers as the WSC seems close to barotropic (Fahrbach et al. 2001).

The horizontal cross-section area $A$ of the water column was chosen to be $1 \mathrm{~m}^{2}$ so that one directly can interpret $Q_{a}^{*}$ as a heat flux through a unit surface area (i.e. think $Q_{a}^{*}$ in units $\mathrm{W} \mathrm{m}^{-2}$ ) if one assumes that all this heat was lost vertically through the top surface of the water column, e.g. to the atmosphere.

On the basis of our "climatological snapshots" of the summer and winter seasons we cannot estimate the magnitude of the local term $Q_{l}$. Haugan (1999b) observed local cooling averaging $1{ }^{\circ} \mathrm{C}$ in the upper $200 \mathrm{~m}$ during two months in late fall 1998 over the upper slope and noted that this cooling gives a non-negligible contribution to the heat budget in fall (ca. $150 \mathrm{~W} \mathrm{~m}^{-2}$ for the upper $200 \mathrm{~m}$ layer). As our time series are centred roughly on the time of local temperature minimum and maximum in the winter and summer, respectively, there should, however, be no significant contribution from this term as $\partial T / \partial t$ is about 0 . Thus, $Q^{*}{ }_{a}$ represents well the total heat loss rate, and comparison of the values in Table 1 with surface heat exchange is justified.

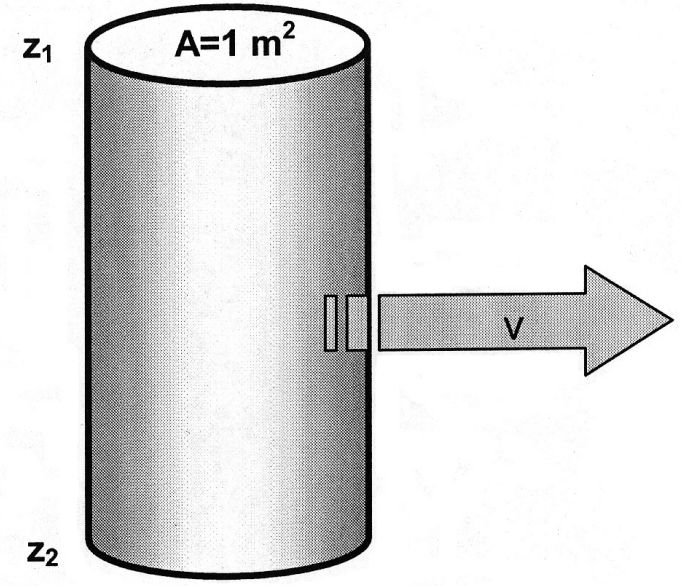

Fig. 6. Schematic illustration of the water column assumed in Eq. (2).

\section{Discussion}

The observed cooling and freshening of the ca. 0-100 m surface layer can easily be attributed to two main processes: surface heat flux and exchange with colder and fresher shelf waters and drift ice. The estimates of Häkkinen \& Cavalieri (1989) show surface heat flux in the range of -250 to $+50 \mathrm{~W} \mathrm{~m}^{-2}$ in August-October and -450 to $0 \mathrm{~W} \mathrm{~m}^{-2}$ in March-May in our study area (monthly means, upward flux is negative), which 
is not different from our estimates of $Q^{*}$ for the $0-100 \mathrm{~m}$ layer: $-130 \mathrm{~W}\left(\mathrm{~m}^{-2}\right)$ in the summer and $-350 \mathrm{~W}\left(\mathrm{~m}^{-2}\right)$ in the winter $\left(\mathrm{m}^{-2}\right.$ in parentheses means assuming that all heat is lost vertically through the water surface) although the values of Häkkinen \& Cavalieri (1989) do not include heat losses to ice melting or exchange with shelf waters. Deeper convection, reaching even down to $200-300 \mathrm{~m}$, may occasionally occur in the winter (cf. Boyd \& D'Asaro [1994] who observed very shallow and variable mixed layers over the WSC in January-February 1989). $Q_{a}^{*}$ for the $0-250 \mathrm{~m}$ layer is $-830 \mathrm{~W}\left(\mathrm{~m}^{-2}\right)$ (Table 1$)$.

While the surface layer is an important component in air-ice-sea interaction affecting e.g. atmospheric heat fluxes and position of the Arctic sea ice edge near Spitsbergen, the main heat transport to the Atlantic layer of the Arctic Ocean does not occur in the ca. $0-100 \mathrm{~m}$ surface layer, which is eventually mixed up with polar waters north of Svalbard to become the cold polar mixed layer, but below that in the subsurface ca. 100-500 m layer of the WSC (Rudels et al. 1999). The rate of cooling of this layer is thus directly coupled to the Arctic Ocean heat balance. The heat loss estimate of the 100-500 m layer of the upper-slope domain is actually 2.5-3 times as large as the heat loss estimate of the $0-100 \mathrm{~m}$ surface layer (Table 1). Where does all this heat go?

Helland-Hansen \& Nansen (1912) and Boyd \& D'Asaro (1994) have given estimates of northward cooling and freshening in the larger-scale WSC based on data from a single cruise, and Manley (1995), based on extensive databases. Helland-Hansen \& Nansen observed northward cooling of $0.21^{\circ} \mathrm{C} / 100 \mathrm{~km}$ in the $100-400 \mathrm{~m}$ layer in July 1910 between $75^{\circ}$ and $79^{\circ} \mathrm{N}$, which is similar to our mean value $0.20^{\circ} \mathrm{C} / 100 \mathrm{~km}$ for the 100-500 m layer. Their northward freshening estimate (a decrease in maximum salinity between $76^{\circ}$ and $80^{\circ} \mathrm{N}$ ) was $0.019 \mathrm{psu} / 100 \mathrm{~km}$, which is twice as much as our mean value for the 100-500 m layer. Helland-Hansen \& Nansen explained the northward cooling and freshening of the subsurface WSC by mixing with shelf and offshore waters.

Comparison with the mean heat loss values of Manley (1995) is somewhat difficult due to different methodology; Manley considered only the AW class $\left(T>3{ }^{\circ} \mathrm{C}, S>34.9 \mathrm{psu}\right)$ in the WSC. The average properties of his "Svalbard branch" (the WSC branch closest to the coast) indicated some mixing with coastal waters. Manley also con- cluded that his "Yermak Branch", offshore of the Svalbard branch, had the strongest AW properties. This is in contradiction with our conception that the warmest and most saline waters are actually found close to the shelf break (Fig. 1). This contradiction is apparently owing to the fact that Manley also included the cooler shelf waters in his Svalbard branch definition.

Aagaard et al. (1987), Untersteiner (1988), Steele \& Morison (1993), Gascard et al. (1995) and Grønås \& Skeie (1999) have estimated heat loss values just north and south of our study area. Although their estimates are spatio-temporally restricted, and at least the three latter describe results from episodic events, these studies indicate that vertical heat fluxes may be locally enhanced north and south of our study area, closer to the Arctic and Barents sea ice edges.

Boyd \& D'Asaro (1994) estimated $0.46^{\circ} \mathrm{C}$ cooling and $0.019 \mathrm{psu}$ freshening per $100 \mathrm{~km}$ in their "stream-tube-WSC" (their Fig. 6) in JanuaryFebruary 1989. These are ca. $50 \%$ and $400 \%$ larger than our winter values for the 100-500 m layer (Table 1). Boyd \& D'Asaro (1994) noted that the subsurface warm core under the surface layer cooled at a rate $\left(800 \mathrm{~W} \mathrm{~m}^{-2}\right)$ that hardly can be supported by direct vertical heat flux (diapycnal mixing) over the core only. They proposed that energetic eddy fields would diffuse heat offshore along isopycnals from the warm core to the surface layer, which would be cooled by atmosphere and sea ice. However, if we calculate a cooling/freshening ratio from the results of Boyd \& D'Asaro (1994) we get $0.46 \mathrm{~K} / 0.019 \mathrm{psu}=24 \mathrm{~K} / \mathrm{psu}$, which is quite different from the expected ratio of $8-10$ $\mathrm{K} / \mathrm{psu}$ for pure isopycnal mixing at surface pressure (this ratio reaches its maximum value at surface pressure and it was derived from the ratio of haline contraction and thermal expansion coefficients, $\beta / \alpha$, at a salinity of $35 \mathrm{psu}$ and at a temperature range of $2-4^{\circ} \mathrm{C}$ [e.g. Gill 1982]). This shows that isopycnal mixing cannot alone be responsible for all the subsurface cooling.

By utilizing cooling/freshening ratio profiles in the summer season, Saloranta \& Haugan (2001b) studied the role of potential cooling mechanisms including: horizontal and isopycnal mixing both offshore and onshore across the Arctic Front west of Spitsbergen (Saloranta \& Svendsen 2001); vertical mixing (e.g. due to double-diffusion, convection, mechanical stirring); cold dense water flowing from the Barents Sea or from the Spitsbergen shelf down the continental slope to the 
WSC; irreversible upwelling, which would cause the rising motion of colder and slightly fresher deeper waters over the slope; westward spreading of near surface low salinity water (which could also expand the surface area of the slope current exposed to atmospheric cooling and thus make the air-sea heat exchange more effective); baroclinic instability and eddy-supported cross-front heat and salt exchange in the Arctic Front over the deep water to the west and south-west of the WSC. Saloranta \& Haugan (2001b) concluded that none of the investigated mechanisms could alone explain the observed summer cooling/freshening ratios and thus, not surprisingly, a combination of different processes seem to act on cooling the warm core of the WSC.

In summary, it seems that the local heat loss from the subsurface (ca. 100-500 m layer) warm core of the WSC is too large to be attributed to direct vertical heat flux to the atmosphere or to ice melting over the core, agreeing with the results of Boyd \& D'Asaro (1994), especially since the warm core apparently is often separated from the surface by stratification (Boyd \& D'Asaro 1994; Saloranta 2001) which hampers vertical heat fluxes. Yet we must remember that significant uncertainties can be associated with the surface heat flux values in our study area owing to lack of meteorological observations and uncertainties in the parameters of the algorithms used in flux calculations (Taylor 2000). Similarly, our calculated heat loss rate values $Q_{a}^{*}$ rest on the assumption of constant current speed and barotropic steady flow along the slope on average in our long-term study period. As the distance between the 500 and $1200 \mathrm{~m}$ isobaths confining our study domain does not change significantly northwards (Fig. 2), this assumption appears plausible, taking into account the barotropic and slope-confined nature of the warm core. However, one could speculate that, for example, advection and inclusion (instead of mixing) of cold water originating from the shelf into the warm core might contribute to increasing the volume of the current and thus to decreasing the current speed along the slope (via conservation of volume transport).

Agreeing with suggestions by Helland-Hansen \& Nansen (1912) and Boyd \& D'Asaro (1994), it seems that lateral exchange with colder neighbouring waters is the primary mechanism for cooling of the subsurface warm core of the WSC. The heat from this core is thus spread horizontally to a larger area than the one defined by the slope current. However, the offshore isopycnal mixing hypothesis of Boyd \& D'Asaro (1994) must apparently be revised by also considering other mechanisms, such as diapycnal mixing processes and exchange with shelf waters onshore of the WSC.

Of course, the laterally spread heat eventually reaches the sea surface somewhere and is released into the atmosphere or ice melting. Precisely where the heat release occurs depends on the mechanisms responsible for the lateral exchange. Until these are better known, it remains uncertain how and to what extent the heat content of the subsurface warm core of the WSC, and thus the heat transport to the Atlantic layer of the Arctic Ocean, are modulated by sea ice conditions (cf. Aagaard et al. 1987; Haugan 1999b) and surface heat fluxes around Svalbard.

Blindheim et al. (2000) suggested that a high North Atlantic Oscillation index would be connected with an increased temperature in the AW inflowing into the Arctic Ocean due to narrowing surface area of the current and thus reduced vertical heat loss to the atmosphere over the current. However, if lateral mixing dominates the subsurface heat loss, then narrowing of the current would not reduce cooling in the manner suggested by Blindheim et al. (2000). On the contrary, if the narrowing of the current was associated with increased current speed, this might enhance barotropic instabilities and thus lateral mixing.

Acknowledgements.-We thank the Arctic Climate System Study project office, the International Council for the Exploration of the Sea, the Norwegian Institute of Marine Research and the Norwegian Polar Institute for kindly providing data for this study, which was supported by Research Council of Norway (via the programme Arktisk Lys og Varme) and by the Norwegian Institute for Water Research. We also thank the two reviewers for their valuable comments.

\section{References}

Aagaard, K., Foldvik A. \& Hillman S. R. 1987: The West Spitsbergen Current: disposition and water mass transformation. J. Geophys. Res. 92(C4), 3778-3784.

Aagaard, K. \& Greisman P. 1975: Toward new mass and heat budgets for the Arctic Ocean. J. Geophys. Res. Ocean. Atmos. 80, 3821-3827.

Blindheim, J., Borovkov, V., Hansen, B., Malmberg, S. A., Turrell, W. R. \& Østerhus, S. 2000: Upper layer cooling and freshening in the Norwegian Sea in relation to atmospheric forcing. Deep Sea Res. Part I 47, 655-680.

Bourke, R. H., Weigel, A. M. \& Paquette, R. G. 1988: The westward turning branch of the West Spitsbergen Current. J. Geophys. Res. 93(C11), 14065-14077.

Boyd, T. J. \& D'Asaro, E. A. 1994: Cooling of the West Spits- 
bergen Current: wintertime observations west of Svalbard J. Geophys. Res. 99(C11), 22 597-22618.

Fahrbach, E., Meincke, J., Østerhus, S., Rohardt, G., Schauer, U., Tverberg, V. \& Verduin, J. 2001: Direct measurements of volume transports through Fram Strait. Polar Res. $20,217-224$

Gammelsrød, T. \& Rudels, B. 1983: Hydrographic and current measurements in the Fram Strait, August 1981. Polar Res. 1, 115-126.

Gascard, J.-C., Richez, C. \& Rouault, C. 1995: New insights on large-scale oceanography in Fram Strait: the West Spitsbergen Current. In W. O. Smith Jr. \& J. M. Grebmeier (eds.): Arctic oceanography: marginal ice zones and continental shelves. Coastal and Estuarine Studies 49. Pp. 131182. Washington D. C.: American Geophysical Union.

Gill, A. E. 1982: Atmosphere-ocean dynamics. London: Academic Press.

Grønås, S. \& Skeie, P. 1999: A case study of strong winds at an Arctic Front. Tellus 51A, 865-879.

Grotefendt, K., Logemann, K., Quadfasel, D. \& Ronski, S. 1998: Is the Arctic Ocean warming? J. Geophys. Res. 103(C12), 27 679-27687.

Häkkinen, S. \& Cavalieri, D. J. 1989: A study of oceanic surface heat fluxes in the Greenland, Norwegian, and Barents seas. J. Geophys. Res. 94(C5), 6145-6157.

Hanzlick, D. J. 1983: The West Spitsbergen Current: transport, forcing and variability. $\mathrm{PhD}$ thesis, University of Washington, Seattle.

Haugan, P. M. 1999a: On transports of mass, heat and carbon in the Arctic Mediterranean. $\mathrm{PhD}$ thesis, University of Bergen, Norway.

Haugan, P. M. 1999b: Structure and heat content of the West Spitsbergen Current. Polar Res. 18, 183-188.

Helland-Hansen, B. \& Nansen, F. 1912: The sea west of Spitsbergen. Videnskapsselskapets Skrifter I. Mat.-Naturv. Klasse, No. 12. Christiania (Oslo).

Jakobsson, M., Cherkis, N. Z., Woodward, J., Macnab, R. \& Coakley, B. 2000: New grid of Arctic bathymetry aids scientists and mapmakers. Eos Trans. 81, 89-96.

Johannessen, O. M. 1986: Brief overview of the physical oceanography. In B. G. Hurdle (ed.): Nordic seas. Pp. 103127. New York: Springer.

Jónsson, S., Foldvik, A. \& Aagaard, K. 1992: The structure and atmospheric forcing of the mesoscale velocity field in Fram Strait. J. Geophys. Res. 97(C8), 12585-12600.

Loeng, H. 1991: Features of the physical oceanographic conditions of the Barents Sea. Polar Res. 10, 5-18.

Loeng, H., Ozhigin, V. \& Ådlandsvik, B. 1997: Water fluxes through the Barents Sea. ICES J. Mar. Sci. 54, 310-317.

Manley, T. O. 1995: Branching of Atlantic Water within the Greenland-Spitsbergen passage: an estimate of recirculation. J. Geophys. Res. 100(C10), 20627-20634.

Pond, S. \& Pickard G. L. 1993: Introductory dynamical oceanography. 2nd edition. Pp. 288-291. Oxford: Pergamon Press.

Poulain, P.-M., Warn-Varnas, A. \& Niiler, P. P. 1996: Nearsurface circulation of the Nordic seas as measured by Lagrangian drifters. J. Geophys. Res. 101(C8), 18237-18258.

Quadfasel, D., Sy, A. \& Rudels, B. 1993: A ship of opportunity section to the North Pole: upper ocean temperature observations. Deep Sea Res. Part I 40, 777-789.

Rudels, B. \& Friedrich, H. J. 2000: The transformations of Atlantic water in the Arctic Ocean and their significance for the freshwater budget. In E. L. Lewis et al. (eds.): The freshwater budget of the Arctic Ocean. Pp. 503-532. Dortrecht, Netherlands: Kluwer.

Rudels, B., Friedrich H. J. \& Quadfasel D. 1999: The Arctic circumpolar boundary current. Deep Sea Res. Part II 46, 1023-1062.

Rudels, B., Jones, E., Anderson, L. \& Kattner, G. 1994: On the intermediate depth waters of the Arctic Ocean. In O. Johannessen et al. (eds.): The polar oceans and their role in shaping the global environment. Vol. 85. Pp. 33-46. Washington, D. C.: American Geophysical Union.

Saloranta, T. M. 2001: Hydrographic structure of the sea west of Svalbard along and across the continental slope. Reports in Meteorology and Oceanography 2. Geophysical Institute, University of Bergen.

Saloranta, T. M. \& Haugan, P. M. 2001a: Interannual variability in the hydrography of Atlantic water northwest of Svalbard. J. Geophys. Res 106(C7), 13 931-13944.

Saloranta, T. M. \& Haugan, P. M. 2001b: Northward cooling and freshening of the West Spitsbergen Slope Current. In T. M. Saloranta: The sea west of Svalbard: structures, trends and variability in hydrography. $\mathrm{PhD}$ thesis, University of Bergen.

Saloranta, T. M. \& Svendsen, H. 2001: Across the Arctic Front west of Spitsbergen: high-resolution CTD sections from 1998-2000. Polar Res. 20, 177-184.

Schauer, U., Loeng, H., Rudels, B., Ozhigin, V. K. \& Dieck, W. 2002: Atlantic Water flow through the Barents and Kara seas. Deep Sea Res. Part I 49, 2281-2298.

Schauer, U., Muench, R. D., Rudels, B. \& Timokhov, L. 1997: Impact of eastern Arctic shelf waters on the Nansen Basin intermediate layers. J. Geophys. Res 102(C2), 3371-3382.

Simonsen, K. \& Haugan, P. M. 1996: Heat budgets of the Arctic Mediterranean and sea surface heat flux parameterizations for the Nordic seas. J. Geophys. Res. 101(C3), 6553-6576.

Steele, M. \& Morison, J. H. 1993: Hydrography and vertical fluxes of heat and salt northeast of Svalbard in autumn. $J$. Geophys. Res. 98(C6), 10013-10024.

Swift, J. H., Jones, E. P., Aagaard, K., Carmack, E. C., Hingston, M., MacDonald, R. W., McLaughlin, F. A. \& Perkin, R. G. 1997: Waters of the Makarov and Canada basins. Deep Sea Res. Part II 44, 1503-1529.

Taylor, P. K. (ed.) 2000: Final report of the Joint WCRP/ SCOR Working Group on Air-Sea Fluxes (SCOR Working Group 110): intercomparison and validation of oceanatmosphere energy flux fields. WCRP-112, WMO/TD-No. 1036. Geneva: World Meteorological Organization.

Untersteiner, N. 1988: On the ice and heat balance in Fram Strait. J. Geophys. Res. 93(C1), 527-531.

Washington, W. M. \& Meehl, G. A. 1996: High-latitude climate change in a global coupled ocean-atmosphere-sea ice model with increased atmospheric $\mathrm{CO}_{2}$. J. Geophys. Res 101(D8), 12 795-12801.

Woodgate, R. A., Schauer, U. \& Fahrbach, E. 1998: Moored current meters in the Fram Strait at $79^{\circ} \mathrm{N}$ : preliminary results with special emphasis on the West Spitsbergen Current. Ber. Fachbereich Phys. 91. Bremerhaven: Alfred Wegener Institute.

Zhang, J., Rothrock, D. A. \& Steele, M. 1998: Warming of the Arctic Ocean by a strengthened Atlantic inflow: model results. Geophys. Res. Lett. 25, 1745-1748. (Correction in Geophys. Res. Lett. 25, 3541.)

Zhang, Y. \& Hunke, E. C. 2001: Recent Arctic change simulated with a coupled ice-ocean model. J. Geophys. Res. 106(C3), 4369-4390. 